\title{
Phosphorus export from a restored wetland ecosystem in response to natural and experimental hydrologic fluctuations
}

\author{
Marcelo Ardón, ${ }^{1}$ Shaena Montanari, ${ }^{2,3}$ Jennifer L. Morse, ${ }^{1}$ Martin W. Doyle, ${ }^{2}$ \\ and Emily S. Bernhardt ${ }^{1}$ \\ Received 12 October 2009; revised 16 July 2010; accepted 17 August 2010; published 4 December 2010.
}

[1] Wetland restoration is a commonly used approach to reduce nutrient loading to freshwater and coastal ecosystems, with many wetland restoration efforts occurring in former agricultural fields. Restored wetlands are expected to be effective at retaining or removing both nitrogen and phosphorus $(\mathrm{P})$, yet restoring wetland hydrology to former agricultural fields can lead to the release of legacy fertilizer P. Here, we examined $\mathrm{P}$ cycling and export following rewetting of the Timberlake Restoration Project, a 440 ha restored riverine wetland complex in the coastal plain of North Carolina. We also compared $\mathrm{P}$ cycling within the restored wetland to two minimally disturbed nearby wetlands and an adjacent active agricultural field. In the restored wetland we observed increased soluble reactive phosphorus (SRP) concentrations following initial flooding, consistent with our expectations that $\mathrm{P}$ bound to iron would be released under reducing conditions. SRP concentrations in spring were 2.5 times higher leaving the restored wetland than a forested wetland and an agricultural field. During two large-scale drawdown and rewetting experiments we decreased the water depth by $1 \mathrm{~m}$ in $\sim 10$ ha of inundated wetland for 2 weeks, followed by reflooding. Rewetting following experimental drainage had no effect on SRP concentrations in winter, but SRP concentrations did increase when the experiment was repeated during summer. Our best estimates suggest that this restored wetland could release legacy fertilizer P for up to a decade following hydrologic restoration. The time lag between restoration and biogeochemical recovery should be incorporated into management strategies of restored wetlands.

Citation: Ardón, M., S. Montanari, J. L. Morse, M. W. Doyle, and E. S. Bernhardt (2010), Phosphorus export from a restored wetland ecosystem in response to natural and experimental hydrologic fluctuations, J. Geophys. Res., 115, G04031, doi:10.1029/2009JG001169.

\section{Introduction}

[2] Wetland restoration is increasingly used to reduce nutrient loading of downstream freshwater and coastal ecosystems [Verhoeven et al., 2006], with much wetland restoration occurring in marginally productive agricultural fields [Zedler, 2003], and supported by government programs in both the United States [Zedler, 2003] and Europe [Hansson et al., 2005]. Restoring the ability of wetlands to retain or transform nutrients in agricultural lands presents various challenges due to the legacy of disturbances to soil and hydrology associated with agriculture, including loss of soil organic matter, soil compaction, fertilizer application,

\footnotetext{
${ }^{1}$ Department of Biology, Duke University, Durham, North Carolina, USA.

${ }^{2}$ Department of Geography, University of North Carolina at Chapel Hill, Chapel Hill, North Carolina, USA.

${ }^{3}$ Now at Richard Gilder Graduate School, American Museum of Natural History, New York, New York, USA.

Copyright 2010 by the American Geophysical Union. 0148-0227/10/2009JG001169
}

drainage and pumping [Zedler, 2003]. Moreover, wetland restoration in former agricultural fields can create biogeochemical conditions that mobilize nutrients, an unintended consequence of such programs.

[3] Many wetland restoration projects seek to reduce both nitrogen $(\mathrm{N})$ and phosphorus $(\mathrm{P})$ in surface water [Verhoeven et al., 2006], however the biogeochemical conditions necessary to promote denitrification (which removes $\mathrm{N}$ from surface waters) might facilitate $\mathrm{P}$ release. $\mathrm{P}$ availability in wetlands is primarily controlled by geochemical sorption onto soil minerals and biotic uptake and mineralization [Richardson, 1985]. Adsorption of inorganic $\mathrm{P}$ onto noncrystalline $\mathrm{Al}$ and $\mathrm{Fe}$ oxides is the dominant mechanism of $\mathrm{P}$ removal in wetlands with acidic soils [Richardson, 1985]. Predicting the effect of flooding on $\mathrm{P}$ cycling is challenging because reducing conditions can affect $\mathrm{P}$ sorption capacity both positively and negatively. Flooding promotes the creation of noncrystalline forms of $\mathrm{Fe}$ and $\mathrm{Al}$ and organic matter-Al complexes, increasing $\mathrm{P}$ sorption capacity [Darke and Walbridge, 2000]. In contrast, flooding and anoxic conditions can lead to the reduction of 
$\mathrm{Fe}(\mathrm{III})$ to $\mathrm{Fe}(\mathrm{II})$, which releases $\mathrm{P}$ bound to oxidized $\mathrm{Fe}$ minerals in the soil [Reddy et al., 1999]. Droughts, and associated oxic conditions, can enhance mineralization of organic forms of $\mathrm{P}$, leading to mobilization of bioavailable forms of P [Van Dijk et al., 2004].

[4] Restoring wetland hydrology to former agricultural fields can lead to the mobilization of legacy $\mathrm{P}$, also called memory $\mathrm{P}$, accumulated from fertilizer application $[$ Reddy and DeLaune, 2008]. The release of this legacy $\mathrm{P}$ can be due to both the reduction of $\mathrm{Fe}$ (III) during anoxic conditions leading to the release of iron-bound $\mathrm{P}$ and to mineralization of organic $\mathrm{P}$ under oxic conditions during dry periods. Various laboratory and short-term studies have reported increases in P dissolution from soils due to flooding and drainage cycles of former agricultural lands [Aldous et al., 2005, 2007; Bostic and White, 2007; Corstanje and Reddy, 2004; Pant and Reddy, 2003; Van Dijk et al., 2004] and in response to storms [Novak et al., 2007]. Much of this research has relied mostly on laboratory or lysimeter-scale measurements of $\mathrm{P}$ from soils. There has been limited research in situ on the relationships between fluctuating water tables in a restored wetland and P export (but see Ardón et al. [2010] and Duff et al. [2009]).

[5] We previously reported water and nutrient $\left(\mathrm{NH}_{4}^{+}, \mathrm{NO}_{3}^{-}\right.$, TDN, DON, TP and SRP) budgets following the reflooding of a former agricultural wetland as part of stream and wetland restoration in the Timberlake Restoration Project (TLRP), in the coastal plain of North Carolina [Ardón et al., 2010]. In the first 2 years following hydrologic reconnection, a mass balance for $\mathrm{P}$ for this large restored wetland documented a release of $0.6 \mathrm{~kg} \mathrm{TP} \mathrm{ha} \mathrm{yr}^{-1}$ and an $8 \mathrm{X}$ increase in annual TP export relative to estimated prerestoration export [Ardón et al., 2010]. P export from this site is important because the downstream Albemarle Sound is considered to be P limited, with SRP concentrations usually being less than $0.04 \mathrm{mg} / \mathrm{L}$ [Lin et al., 2007; Richardson, 1983]. Here, we examined how natural and experimental hydrologic fluctuations determine P cycling within a restored wetland. We anticipated that: (1) we would measure release of $\mathrm{P}$ immediately upon initial reflooding a former agricultural field as part of restoration and during storm events; (2) concentrations and export of SRP and TP from the restored wetland would be higher than a forested wetland but lower than an agricultural field; (3) soil TP in restored wetland would decline over time due to increased P export; and (4) large drawdown experiments would increase P export from the restored wetland. To elucidate the recovery trajectory of this restored wetland we also compared soil parameters and soil solution $\mathrm{P}$ to two nearby minimally impacted wetlands and an active agricultural field. Due to the 20 years of agricultural activities in TLRP, we expected to see higher soil solution $\mathrm{P}$ in the restored wetland than the reference wetlands and soil parameters from TLRP to resemble more an active agricultural field than reference wetlands.

\section{Site Description}

\subsection{Albemarle Peninsula}

[6] Located in the northern coastal province of $\mathrm{NC}$, the Albemarle Peninsula extends $5000 \mathrm{~km}^{2}$, with $2700 \mathrm{~km}^{2}$ under $1 \mathrm{~m}$ elevation [Poulter and Halpin, 2008]. The
Peninsula is located between the Albemarle Sound (north), Croatan Sound (east) and Pamlico Sound (south). Mean annual temperature is $16.6^{\circ} \mathrm{C}$ and mean annual precipitation is $1330 \mathrm{~mm} / \mathrm{yr}$ (Plymouth Weather Station, Washington Country, NC). Much of this region historically was covered by pocosin wetlands (evergreen shrub-scrub), but by 1979 only $30 \%$ of the original wetlands remained [Richardson, 1983]. Much of the landscape was deforested at the beginning of the 20th century and drained for agriculture in the 1970s-1980s [Carter, 1975]. Agriculture continues to be the predominant land use, with $80 \%$ of the agricultural area considered marginal because it requires active pumping to allow agriculture [Neely, 2008]. A critical feature of this area is the bidirectional hydrology of rivers, streams and wetlands due to wind-driven tides [Poulter et al., 2008]. Farmers constructed one-direction pump stations at the end of their properties to actively pump and maintain low-water tables needed for agriculture. These pump stations also prevented the upstream movement of water due to wind tides. Restoring the hydrology to such an area is done by removing pump stations and allowing the bidirectional movement of water.

\subsection{Timberlake Restoration Project}

[7] Timberlake Restoration Project (TLRP), located in the Albemarle Peninsula in Tyrrell County, NC (35 $54^{\prime} 22^{\prime \prime} \mathrm{N}$ $76^{\circ} 09^{\prime} 25^{\prime \prime} \mathrm{W}$ ), is part of Great Dismal Swamp Mitigation Bank, LLC. The main objective of the mitigation bank is "to establish self-sustaining, functioning aquatic systems to replace the function and acreage of wetlands and other aquatic resources anticipated to be adversely affected" (U.S. Army Corps of Engineers, Umbrella memorandum of agreement between bank sponsors, p. 27, 1997). The total 1704.2 ha compensatory mitigation site is composed of: 420 ha of mature forested wetland that was never in agriculture (For), 787 ha of forested wetland under a preservation easement (preservation area, PA), 57.2 ha of drained shrub-scrub, and 440 ha of former agricultural fields undergoing stream and wetland restoration (RW). The site drains to the Albemarle Sound via the Little Alligator River $(3 \mathrm{~km}$ from the site). Elevation in the site ranges from $-0.4 \mathrm{~m}$ to $5.1 \mathrm{~m}$ above sea level [Needham, 2006]. The two major soil series in the site are Ponzer muck (loamy, mixed, dysic, thermic Terric Haplosaprists) and Hyde loam (fine-silty, mixed active, thermic Typic Umbraquults, USDA SSURGO Database 2005). There are also areas of Roper muck, Weeksville silt loam, and Pungo muck [Needham, 2006].

[8] The focus of this study was the 440 ha former agricultural field (RW), which is being restored into stream, riverine and nonriverine wetlands (Figure 1). After the last corn harvest in August 2004 land movement was begun to restore the hydrology to its preagricultural state. This included filling $53 \mathrm{~km}$ (33 miles) of "vee" ditches (approximately 90-100 $\mathrm{cm}$ deep), plugging sections of the main canal (approximately $3 \mathrm{~m}$ deep), and creating a focused zone of preferential flow by connecting the lowestelevation areas across the site (Figure 1). Restoration also included planting 750,000 trees from 10 native wetland species: Taxodium distichum, Nyssa sylvatica var. biflora, Nyssa aquatica, Fraxinus pennsylvanica, Salix nigra, Chamaecyparis thyoides, Quercus nigra, Quercus michauxii, Quercus phellos, and Quercus falcate var. pagodafolia 

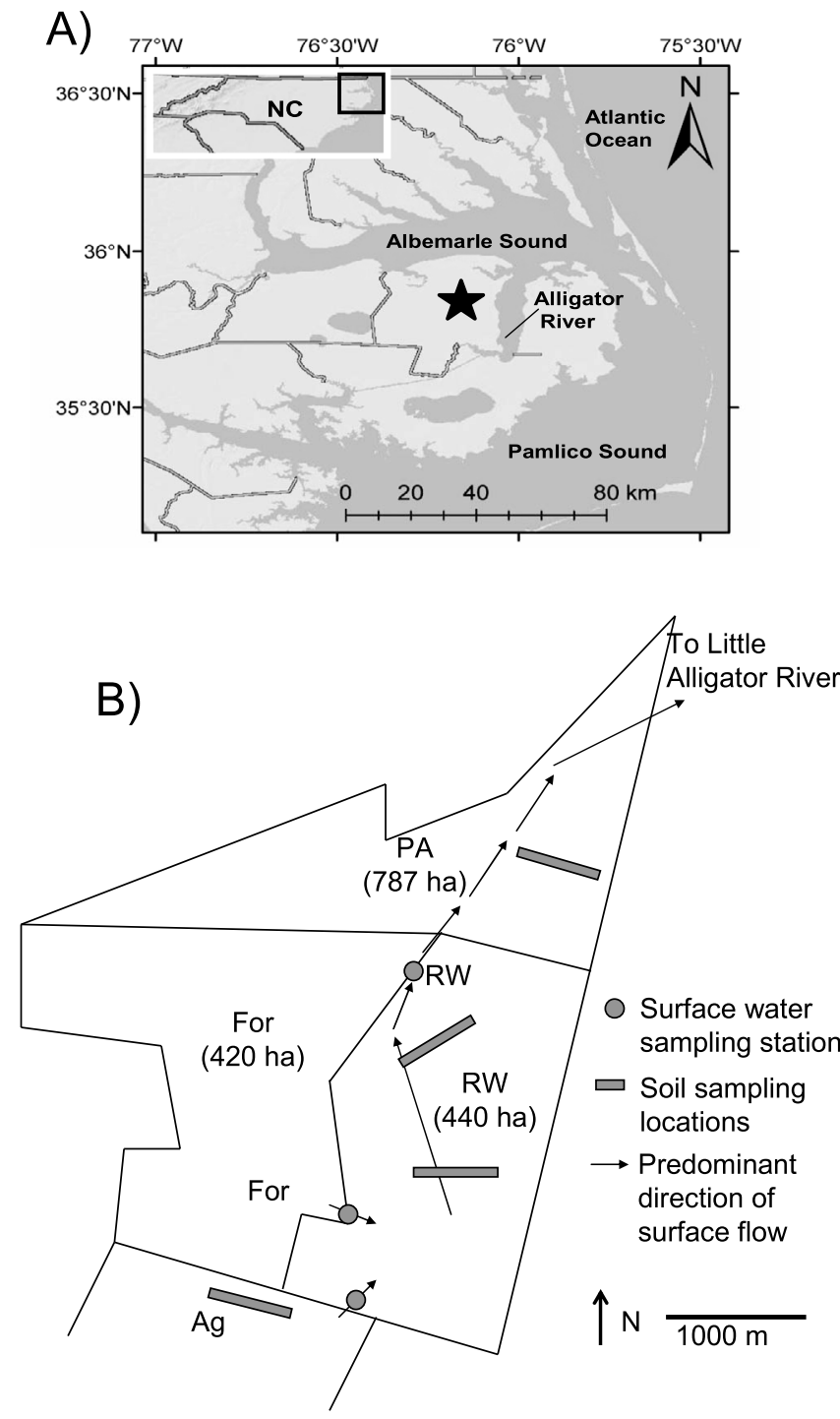

Figure 1. (a) Location of Timberlake Restoration Project (TLRP) in North Carolina. (b) Locations of surface water sampling stations (RW, For, and Ag) and locations where soils and soil solution were sampled. Black arrows indicate area of predominant flow. RW, restored wetland; PA, preservation area; Ag, agricultural field. The other reference wetland that was sampled (PP, Palmetto Peartree Preserve) does not appear in Figure 1b because it is located 5 miles north.

[Needham, 2006]. Disabling the downstream gate-pump system in February 2007 was the final step in the restoration process, reinstating the precipitation and wind tide hydrologic regime and associated groundwater fluctuations. In August 2007 a pump was installed in the upstream end of RW to allow the 2424 ha adjacent farm to pump excess water onto the site.

[9] In addition to the work on RW, we studied two minimally impacted wetlands: the preservation forested wetland (PA) (which is dominated by Belhaven muck (loamy, mixed, dysic, thermic Terric Haplosaprists)) and an area of freshwater wetlands in the nearby (5 miles north of TLRP) Palmetto Peartree Preserve (PP, dominant soil type Dorovan muck, dysic, thermic Typic Haplosaprists). To contrast the reference wetlands, we also worked in an active agricultural field (Ag, dominant soil type Weeksville silt loam, coarse-silty, mized semiactuve, thermic Typic Umbraquults) immediately south of TLRP (Figure 1).

\section{Methods}

\subsection{Phosphorus in Surface and Rainwater}

[10] To examine $\mathrm{P}$ losses from the restored site (RW), a forested wetland (For) and an agricultural field (Ag) we collected water samples (one filtered with $0.7 \mu \mathrm{m} \mathrm{GF} / \mathrm{F}$ Whatman filter, and one unfiltered) from a constrained outflow in each one (Figure 1) weekly for 2 years (February 2007 to February 2009). Samples were refrigerated and maintained at $4{ }^{\circ} \mathrm{C}$ until analyzed (usually within 3 weeks). On the filtered samples we measured soluble reactive phosphorus (SRP) using the ascorbic acid and molybdenum blue method [American Public Health Association (APHA), 1998] on a Lachat QuickChem automated system (Lachat QuikChem 8000, Lachat Instruments, Milwaukee WI). On the unfiltered samples we measured total phosphorus (TP) using persulfate digestion followed by ascorbic acid and molybdenum blue method as above [APHA, 1998]. Water $\mathrm{pH}$, dissolved oxygen, conductivity, and temperature were measured every time we collected samples using a handheld device (YSI Multiprobe 560, Yellow Springs, OH, United States).

\subsection{Hydrologic Manipulations and Storm Sampling}

[11] Because of the rapid changes expected during the initial flooding, drawdown, and storm events, we also conducted high frequency sampling for specific windows of time. During the initial flooding of RW (28 February to 3 March 2007) we collected samples every $6 \mathrm{~h}$ using ISCO automated samplers (ISCO 6712, Teledyne ISCO, Ohio). We conducted two drawdown experiments in RW, one in winter (4-18 February 2008) and one during the summer (18 August to 2 September 2008). During the drawdown experiments we activated the pump (70,000 gallons $\left.\mathrm{min}^{-1}\right)$ on the downstream end of RW to decrease water depth by $1 \mathrm{~m}$ to approximately 10 ha for 2 weeks. During experimental drawdown we collected samples every 4-12 h depending on how fast surface water elevation was changing. We also conducted high frequency (samples every 4-6 h) sampling for 10 storm events over the 2 years for the RW and eight storms for the For. We compared concentrations and fluxes of SRP and TP from an active agricultural field (Ag), a mature forested wetland (For), and the former agricultural field undergoing restoration (RW).

\subsection{Soil Solution $\mathbf{P}$}

[12] To examine potential $P$ release from the sediment to surface water, we measured soil solution every $2-4$ months on 33 sampling points across the elevation gradient at the site. We sampled pore water from a network of piezometers (wetter conditions) and lysimeters (drier conditions) at $15 \mathrm{~cm}$ depth. In seven sites we also installed piezometers at 30,60 and $100 \mathrm{~cm}$. Samples were collected first by purging the piezometers, or creating a vacuum $(40 \mathrm{kPa})$ on the lysimeters, and then collecting water samples the next 
day. Samples were collected in HDPE plastic bottles, one unfiltered and one filtered (Whatman GF/F, $0.7 \mu \mathrm{m}$ ) and refrigerated until analyzed as described above. If we did not have enough sample for both SRP and TP, we prioritized SRP. We also collected soil solution from 5 piezometers (15 cm deep) before, during, and after the summer drawdown experiment (18 August to 2 September 2008).

[13] Each soil solution sampling point was instrumented with 5 platinum electrode redox probes [Vepraskas et al., 2004] along with a water level recorder (Solinist Levelogger Gold, Canada) at $15 \mathrm{~cm}$ depth. To examine the effects of hydrology on soil solution within RW we classified the sampling sites according to the average water table depth (WTD), such that there were 3 groups: RW-Dry (mean WTD $<-20 \mathrm{~cm}$ ), RW-Int (mean WTD between -15 and $0.5 \mathrm{~cm}$ ), and RW-Wet (mean WTD $>5 \mathrm{~cm}$ ). In addition to the points within RW, we instrumented 5 sampling points in preservation wetland (PA), Palmetto Peartree Preserve (PP) and the agricultural field $(\mathrm{Ag})$.

\subsection{Soil Analyses}

[14] To examine changes in soil nutrient pools, we collected soil samples in 2006 (August and November), 2007 (June and October) and 2008 (October). Soil cores (5 cm internal diameter, $30 \mathrm{~cm}$ long) were collected from 12 points from the three hydrology groups within RW described above: RW-Dry $(\mathrm{n}=4)$, RW-Int $(\mathrm{n}=4)$, and RW-Wet $(\mathrm{n}=4)$. In addition to sampling within RW, on June 2007 and October 2008 we collected soil samples from 5 sampling locations in two nearby forested wetlands (PA and $\mathrm{PP}, \mathrm{n}=5$ each $)$ and an active agricultural field $(\mathrm{Ag}, \mathrm{n}=5)$. Soil samples were stored on ice during the trip to the laboratory where they were stored at $4^{\circ} \mathrm{C}$ until processed. Each sample was sectioned into the top $15 \mathrm{~cm}$ and $15-30 \mathrm{~cm}$, and then sieved by hand ( $2 \mathrm{~mm}$ sieve) to remove large plant and root material. Here, we report data from the top $15 \mathrm{~cm}$, where most of the biological activity occurs. Soil carbon and nitrogen were measured on a Carlo Erba Elantech Model NC2100 elemental analyzer (ThermoQuest Italia, Milan, Italy). Total phosphorus was determined after nitric-perchloric digest of $0.6 \mathrm{~g}$ of dried soils [Carter, 1993] and analyzed on Lachat QuickChem as described above.

[15] We conducted single point $\mathrm{P}$ isotherms on the 2007 soil samples to determine the capacity of the soils to sorb P. We determined a single point $\mathrm{P}$ isotherm according to [Axt and Walbridge, 1999]. Sediments (2.0 g of dry weight equivalent) were shaken for $24 \mathrm{~h}$ in $25 \mathrm{ml}$ of $0.01 \mathrm{M}$ $\mathrm{CaCl}_{2}$ containing $130 \mathrm{mg} \mathrm{P} / \mathrm{L}$ as $\mathrm{KH}_{2} \mathrm{PO}_{4}$. The samples were then centrifuged for $20 \mathrm{~min}$ at $3400 \mathrm{rpm}$, filtered (Whatman GF/F, $0.7 \mu \mathrm{m}$ ) and analyzed for SRP as described above. We estimated the phosphorus sorption index (PSI) as $x / \log c$, where $x=\mathrm{P}$ adsorbed by the soil (mg P per $100 \mathrm{~g}$ of soil) and $c=$ the equilibrium solution SRP concentration after $24 \mathrm{~h}$ of shaking (in $\mu \mathrm{mol} / \mathrm{L}$ ).

[16] Because Fe and $\mathrm{Al}$ have been shown to be important controls on $\mathrm{P}$ sorption we also measured oxalate-extractable $\mathrm{Al}\left(\mathrm{Al}_{\mathrm{ox}}\right)$ and $\mathrm{Fe}\left(\mathrm{Fe}_{\mathrm{ox}}\right)$ on the 2007 samples. We extracted $0.4 \mathrm{~g}$ of soil (dry weight equivalent) using $0.2 \mathrm{M}$ ammonium oxalate and $0.2 \mathrm{M}$ oxalic acid, by shaking for $4 \mathrm{~h}$ in darkness (soil solution ratio 1:100) [Darke and Walbridge, 1994]. Two drops of Superfloc $0.4 \%$ were added before being centrifuged for $5 \mathrm{~min}$ at $2000 \mathrm{rpm}$. Samples were filtered
(Whatman no. 42) and stored at $4^{\circ} \mathrm{C}$ until analyzed using atomic absorption spectroscopy (AAS 5100PC; Perkin Elmer, Norwalk, CT, United States).

\subsection{Fates of Legacy $P$}

[17] To examine changes in P cycling over time in RW we used a space-for-time substitution to construct our best educated guess for $\mathrm{P}$ budgets under natural wetland conditions, under active agriculture, and following the hydrologic transition due to wetland restoration. At each stage we combined our own data with literature values to examine the major pools (soil and plant biomass) and fluxes (surface water export) of P. To estimate soil and plant biomass $\mathrm{P}$ pools of a natural wetland we used soil TP data from our two minimally impacted wetland sites (PA and PP) and literature values for plant biomass TP from Mitsch et al. [1979]. To estimate surface water export of $P$ during the natural wetland condition we used our measured TP export from the For site, which drains a mature forested wetland. We combined estimates of $\mathrm{P}$ in loose sediments (floc), periphyton, and macrophytes from Noe and Childers [2007] to estimate the size of the actively cycled $\mathrm{P}$ pool. To approximate changes in conversion to agriculture we estimated gains in soil P due to fertilizer application by multiplying the annual fertilizer application rates used in the area [Crozier, 2000; K. Cherry, Cherry Farms, Tyrrell County, North Carolina, personal communication, 2009] by the 20 years the site was under agriculture, while accounting for losses due to crop removal (K. Cherry, personal communication, 2009). We estimated surface water P losses during agriculture from measured $\mathrm{P}$ concentrations and fluxes from Ag [Ardón et al., 2010]. To estimate plant biomass $\mathrm{P}$ due to the 750,000 trees planted as part of the restoration, we used measurements of tree diameter collected for mitigation monitoring reasons (R. Needham, unpublished data, 2009). We used annual measurements of tree diameter at breast height from 38 to 73 plots ( 0.04 ha) across RW taken in 2006, 2007 and 2008. We used annual growth that occurred between each of those years and allometric equations from Jenkins et al. [2003] and Schroeder et al. [1997] to estimate plant biomass $\mathrm{C}$. We increased the total plant biomass carbon estimated through the allometric equations by $25 \%$ to estimate belowground biomass [Schlesinger, 1997]. We then converted estimates of plant biomass $\mathrm{C}$ to biomass $\mathrm{P}$ using a C:P molar ratio of 1378 based on published data of $\%$ $\mathrm{P}$ for some of the most common trees on the site (Taxodium distichum, Nyssa sylvatica, Nyssa aquatica and Quercus sp. [Bedford et al., 1999]). We used a weighted average of soil TP measurements derived from 2006 (preflooding), 2007, and 2008 from the three hydrologic groups according to their relative area (RW-Dry 41\%, RW-Int $41 \%$, and RW-Wet $18 \%)$. To get a "back of the envelope" estimate of the time it will take RW to return to preagricultural state we estimated the amount of legacy fertilizer TP that could be lost as the difference between the 2008 soil TP in RW and soil TP in our two reference wetlands. We then used our measurements of TP export from RW and estimates of plant biomass P uptake as the two means of losses of P from the soil into long-term storage or solute export. This calculation relies on three simplifying assumptions: (1) surface export will be constant over time; (2) plant $\mathrm{P}$ uptake will also be constant; and 

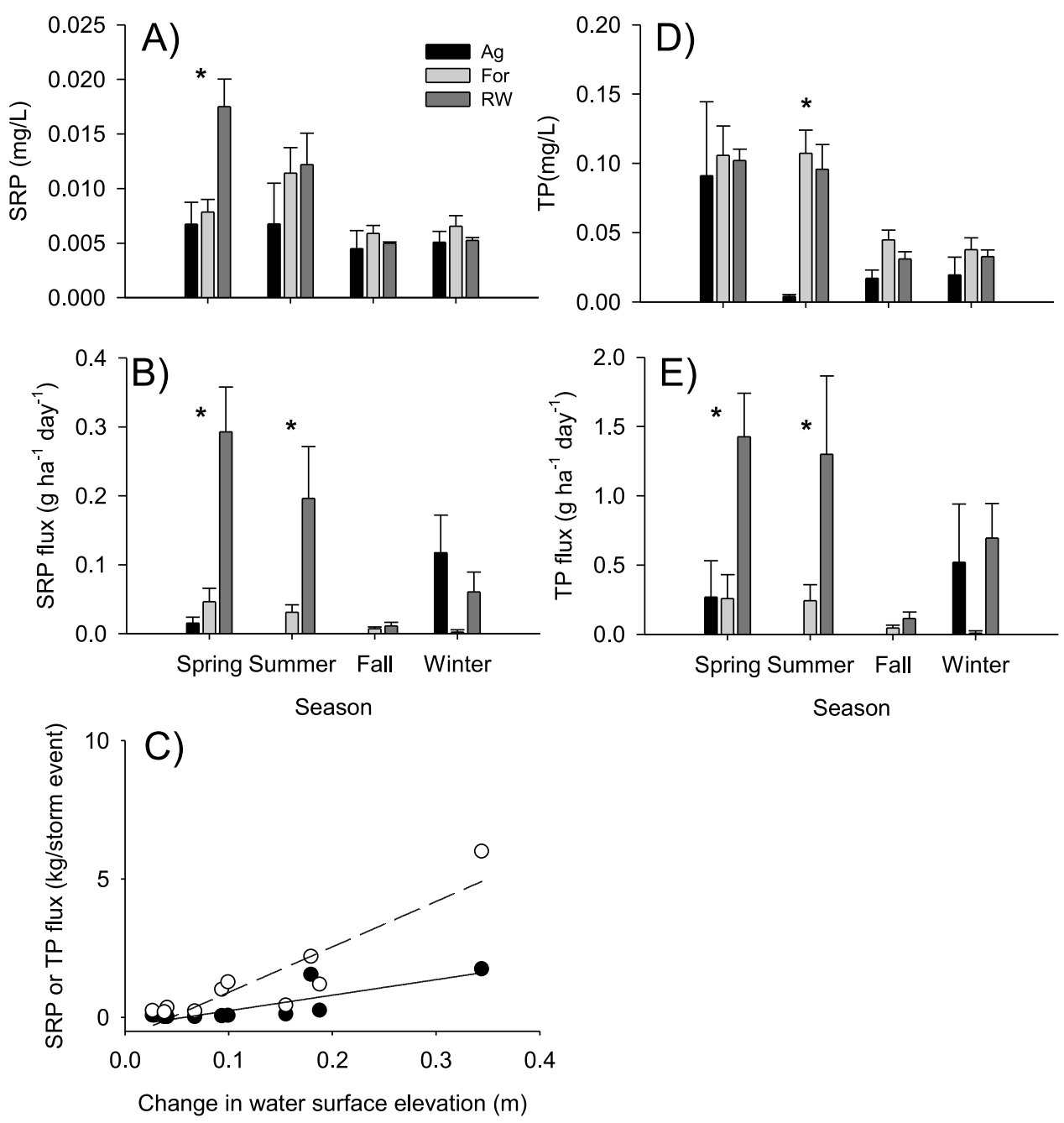

Figure 2. Mean ( \pm standard error) concentrations $(\mathrm{mg} / \mathrm{L})$ and daily fluxes $\left(\mathrm{g} \mathrm{ha}^{-1} \mathrm{~d}^{-1}\right)$ of $(\mathrm{a}$ and b) SRP and (d and e) TP for an active agricultural field (Ag), a forested wetland (For) and restored wetland (RW). (c) Relationships between maximum increase in water surface elevation due to rain events and SRP (solid circles) and TP (open circles) export (kg/storm event) over 2 years from RW. Regressions in Figure 2c: TP $\mathrm{r}^{2}=0.81, \mathrm{p}<0.001$, SRP $\mathrm{r}^{2}=0.62, \mathrm{p}<0.001$. Asterisks denote significant differences from post hoc Tukey HSD.

(3) changes in bulk density of the soils due to peat and sediment accumulation will not affect $\mathrm{P}$ release or retention.

\subsection{Statistical Analysis}

[18] To compare the concentration and export of SRP and TP among sites and seasons, we used two-way analysis of variance (ANOVA) on log transformed data with site (For, $\mathrm{RW}$ and $\mathrm{Ag}$ ) and season (spring, summer, fall, and winter) as factors, followed by post hoc Tukey HSD. Because the pump that drains the Ag was only activated 28 days over the 2 years, we did not include fluxes from the $\mathrm{Ag}$ field in statistical analyses (but we did include concentrations from $\mathrm{Ag}$ site in statistical analyses). We used linear regression to determine relationships between changes in water surface elevation and SRP or TP export. We used analysis of covariance (ANCOVA) to compare soil TP between the three hydrologic groups (RW-Dry, RW-Int and RW-Wet) and 3 sampling years (2006, 2007 and 2008). We used linear regression to examine relationships between $\mathrm{Al}$ and
Fe and $\mathrm{P}$ sorption index. All analyses were conducted using JMP Statistical software (SAS, Cary, North Carolina).

\section{Results}

\subsection{Hydrologic Losses and Drawdown Experiments}

[19] Over the 2 years we sampled, we found clear seasonal patterns in both TP and SRP concentrations $(\mathrm{mg} / \mathrm{L})$ and export $\left(\mathrm{g} \mathrm{ha}^{-1} \mathrm{~d}^{-1}\right)$ leaving RW, For, and Ag (Figure 2). $\mathrm{TP}$ and SRP concentrations were higher during spring and summer months in both sites (TP ANOVA F $=8.03, \mathrm{df}=299$, $\mathrm{p}<0.001$; SRP ANOVA $\mathrm{F}=4.49, \mathrm{df}=299, \mathrm{p}<0.001$, Figure 2). SRP concentrations were 2.5 times higher leaving RW $(0.017 \pm 0.0025 \mathrm{mg} / \mathrm{L})$ than the For $(0.007 \pm$ $0.0025 \mathrm{mg} / \mathrm{L})$ and $\mathrm{Ag}(0.006 \pm 0.0025 \mathrm{mg} / \mathrm{L})$ during spring (Tukey HSD $p<0.0001$, Figure 2a). TP concentrations were higher in For and RW than the Ag sites during summer (Tukey HSD $p<0.001$ ). Fluxes of TP and SRP were significantly higher in RW than For in spring and summer 


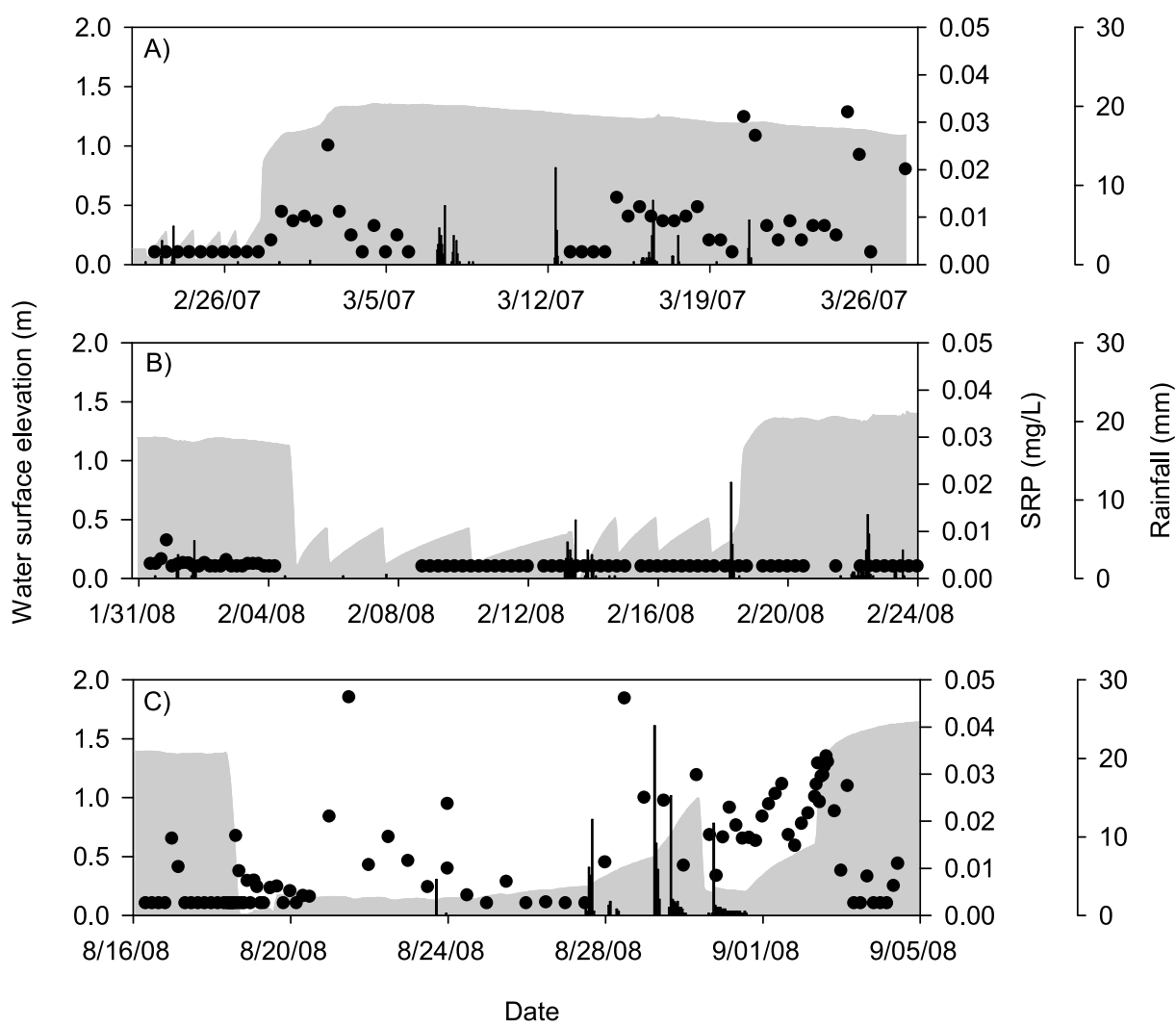

Figure 3. (a) SRP concentrations during initial flooding; and two experimental drawdown and reflooding events: (b) 2-18 February 2008 and (c) 18 August to 2 September 2008. Gray shaded areas indicate water surface elevation $(\mathrm{m})$, solid circles are SRP concentration $(\mathrm{mg} / \mathrm{L})$, and vertical lines indicate rainfall events $(\mathrm{mm})$.

(SRP: $\mathrm{F}=7.93, \mathrm{df}=211, \mathrm{p}<0.001 ; \mathrm{TP}: \mathrm{F}=4.9, \mathrm{df}=211$, $\mathrm{p}<0.0001$, Figures $2 \mathrm{~b}$ and $2 \mathrm{e})$. There was a significant positive relationship between increases in water surface elevation and SRP and TP export from RW during storms (Figure 2c).

[20] During the initial flooding in February 2007, water depth in RW increased by more than $1 \mathrm{~m}$ in a day, leading to increased SRP concentration (Figure 3a). The experimental drawdown in winter rapidly decreased water depth to prerestoration levels, but did not cause any changes in SRP concentrations (Figure 3b). Average water temperature during the low-water period was $11.5^{\circ} \mathrm{C}$ (range 2 to $21^{\circ} \mathrm{C}$ ). The experimental drawdown in summer also decreased water depth to prerestoration levels, and caused a fourfold increase in SRP concentrations during the dry period (Figure 3c), followed by decreases during the reflooding. Average water temperature during the low-water period was $26.6^{\circ} \mathrm{C}$ (range $20.2^{\circ}-36.1^{\circ} \mathrm{C}$ ).

\subsection{Soil Solution}

[21] We collected and analyzed 190 samples of soil solution over the 2 years from all sites. Soil solution SRP and TP varied across sites and hydrologic group within RW (Table 1 and Figure 4). SRP was higher in the RW-Wet sites than in the other sites, but the difference was not significant (Figure 4a). TP was significantly higher in RW-Wet than the RW-Dry sites (Figure $4 b, d f=189, F=7.24, p<0.001$ ). The SRP:TP ratio in the RW-Dry, RW-Int and Wet sites was similar to the ratio observed in surface water $(0.1-0.17$, Table 1). Due to drought and active pumping of the water table, we were unable to obtain soil solution from the active agricultural field. Soil solution SRP increased during the summer drawdown event (Figure 5). While all wells showed increases, the magnitude of increase was least in the highestelevation well (Figure 5c).

Table 1. Mean and Range (Minimum-Maximum, mg/L) Phosphorus Concentrations in Soil Solution in the Timberlake Restoration Project and Three Reference Sites ${ }^{\mathrm{a}}$

\begin{tabular}{cllc}
\hline Soil Solution & \multicolumn{1}{c}{ TP } & \multicolumn{1}{c}{ SRP } & SRP:TP \\
\hline RW-Dry & 0.063 & 0.011 & 0.17 \\
& $0.0025-0.44$ & $0.0025-0.089$ & \\
RW-Int & 0.103 & 0.016 & 0.16 \\
& $0.0025-0.36$ & $0.0025-0.121$ & \\
RW-Wet & 0.153 & 0.021 & 0.14 \\
PA & $0.01-0.52$ & $0.0025-0.149$ & \\
PP & 0.144 & 0.005 & 0.03 \\
& $0.016-0.48$ & $0.0025-0.016$ & \multirow{2}{*}{ Ag } \\
\hline
\end{tabular}

${ }^{\mathrm{a}} \mathrm{RW}$-Dry, restored wetland dry; RW-Int, restored wetland intermittent; RW-Wet, restored wetland wet; Ag, agricultural field; PA, Timberlake preservation area; PP, Palmetto Peartree Preserve wetlands. See text for definitions of hydrologic groups within RW. 

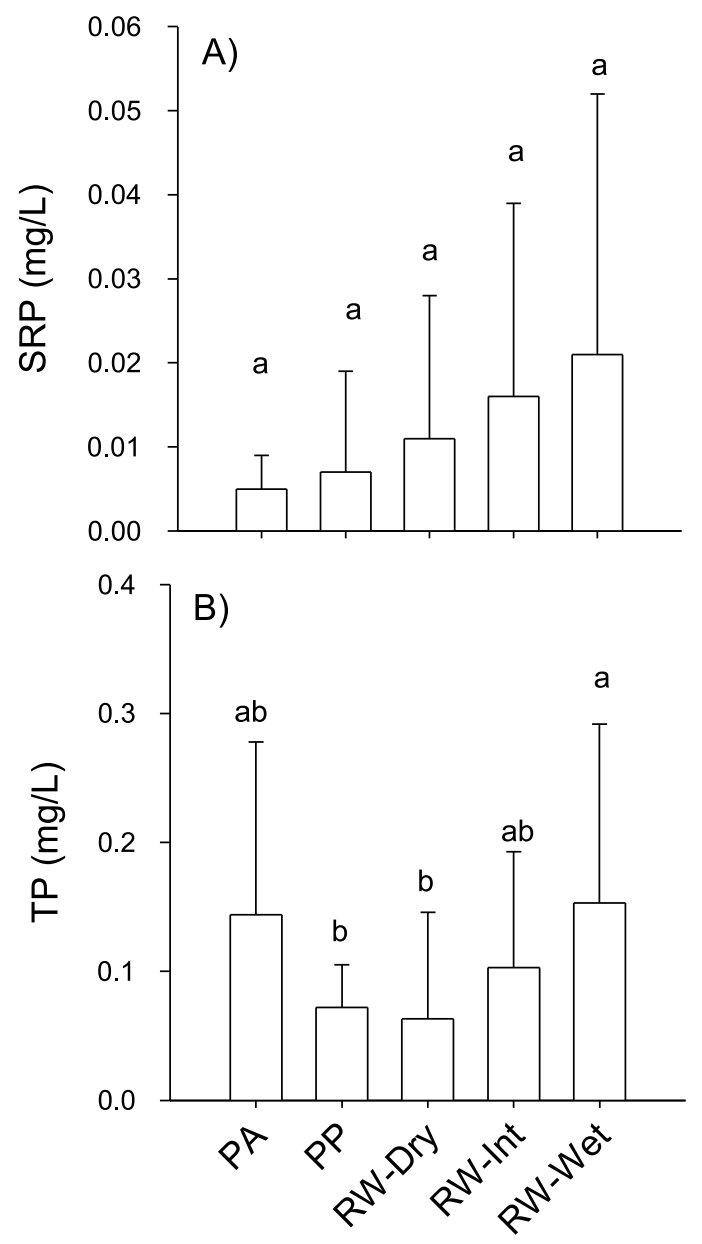

Site

Figure 4. Soil solution (average \pm standard deviation) (a) SRP and (b) TP in two reference wetlands (PA, preservation area; PP, Palmetto Peartree Preserve) and three hydrologic groups within Timberlake Restoration Project over 2 years. RW-Dry, restored wetland dry sites; RWInt, intermittently flooded sites in restored wetland; RWWet, permanently flooded sites in the restored wetland. See text for details of determination of these hydrologic groups. Letters denote significant differences after post hoc Tukey HSD.

\subsection{Soil Pools and Assays}

[22] RW soils had significantly higher bulk density than the reference wetlands and lower than the active farm field $(\mathrm{F}=48.1, \mathrm{df}=65, \mathrm{p}<0.001$, Table 2$)$. The concentrations (in both $\mathrm{mol} / \mathrm{kg}$ and $\mathrm{mol} / \mathrm{m}^{3}$ ) in RW-Dry were similar to the $\mathrm{Ag}$ for $\mathrm{C}, \mathrm{N}, \mathrm{TP}, \mathrm{Al}_{\mathrm{ox}}$ and $\mathrm{Fe}_{\mathrm{ox}}$ (Table 2). The soil characteristics of the RW-Wet tended to be more similar to the two reference wetlands than the RW-Dry or RW-Int (Table 2). The agricultural field had significantly higher $\mathrm{TP}$ in the soil than the other sites $(\mathrm{F}=26.7, \mathrm{df}=65$, $\mathrm{p}<0.001$, Table 2). Within soils in RW there was a significant difference in soil TP among the three hydrologic groups $(\mathrm{F}=11.2, \mathrm{df}=35, \mathrm{p}<0.001)$ and decrease in soil TP with time $(\mathrm{F}=4.2, \mathrm{df}=35, \mathrm{p}<0.05$, Figure 6$)$, but the interaction term was not significant (hydrology by time, $\mathrm{p}=0.9$ ). $\mathrm{P}$ sorption index (PSI) was significantly higher in RW-Wet, RW-Int and $\mathrm{PA}$, and similar between the Ag and one of the reference sites (PP, Table 2). PSI was strongly correlated to $\mathrm{Al}_{\mathrm{ox}}$ but not to $\mathrm{Fe}_{\mathrm{ox}}$ for all sites combined (Figure 7).

\subsection{Fates of Legacy $P$}

[23] Our best estimate of the P budget of a natural wetland in this area before agricultural conversion suggests that $2.9 \mathrm{kmol} \mathrm{P} \mathrm{ha}^{-1}$ are stored in plant biomass, $3.6 \mathrm{kmol} \mathrm{P} \mathrm{ha}^{-1}$ are stored in soil, and $0.003 \mathrm{kmol} \mathrm{P} \mathrm{ha}^{-1} \mathrm{yr}^{-1}$ are exported through surface water. Based on Noe and Childers [2007] we estimate there is approximately $0.28 \mathrm{kmol} \mathrm{P} \mathrm{ha}^{-1}$ in floc, periphyton and macrophytes. Due to the naturally low $\mathrm{P}$ in

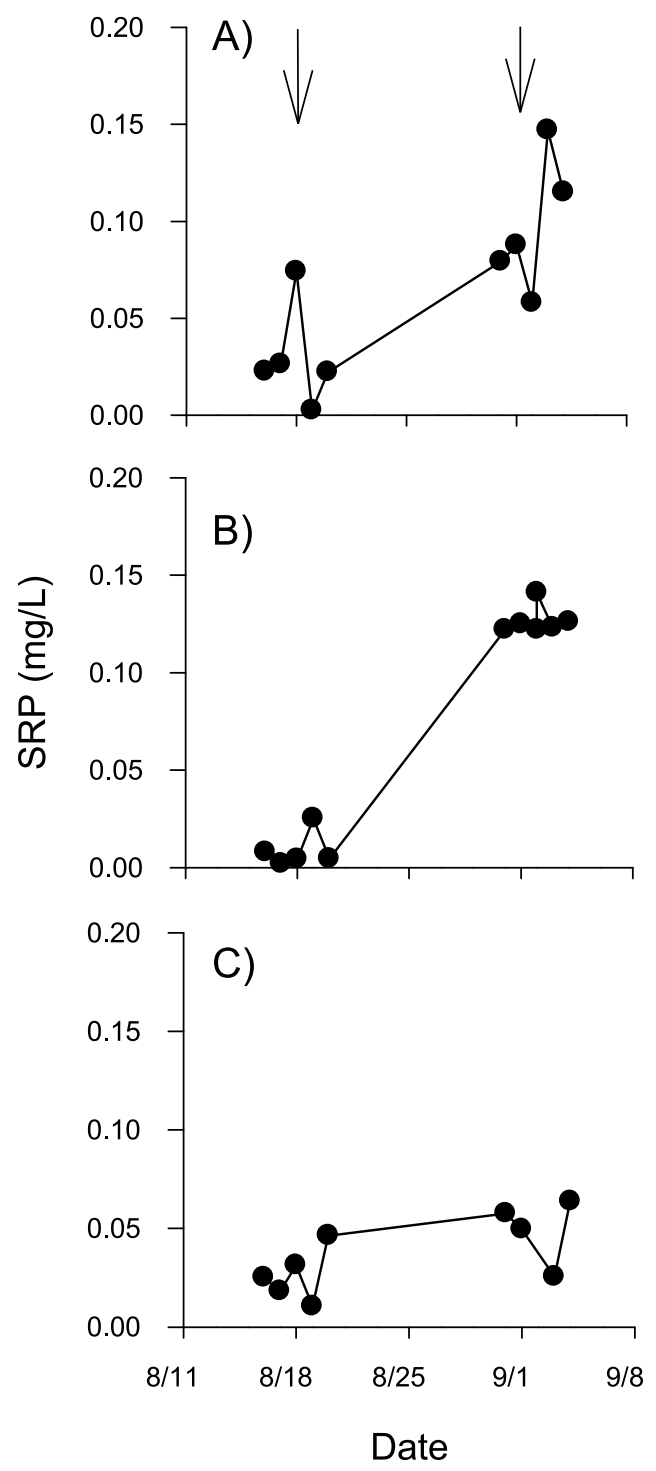

Figure 5. Soil solution SRP $(\mathrm{mg} / \mathrm{L})$ in three sampling wells during the summer drawdown experiment (18 August to 2 September 2008) in Timberlake Restoration Project. Wells spanned a hydrologic gradient: (a) permanently flooded, (b) intermittently flooded, and (c) permanently dry. The site in Figure 5c had the highest elevation, and thus was least affected by the drawdown experiment. Arrows indicate start and end of the pumping. 


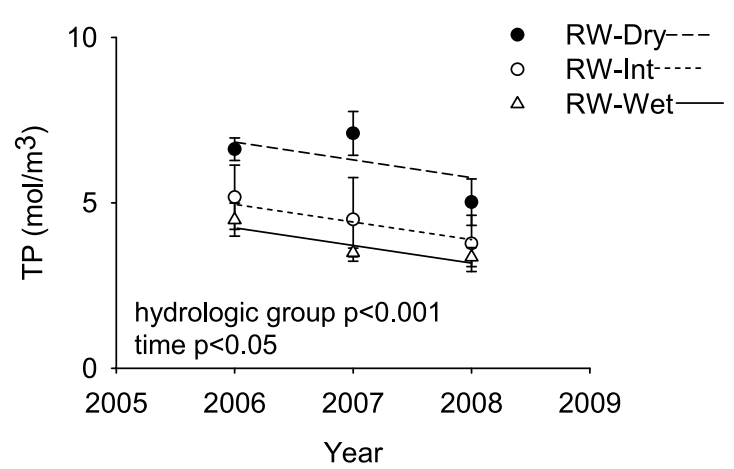

Figure 6. Soil TP (mean \pm standard error) in three hydrologic groups within Timberlake Restoration Project. RW-Dry, restored wetland dry sites; RW-Int, intermittently flooded sites in restored wetland; RW-Wet, permanently flooded sites in the restored wetland. See text for details of hydrologic groups. Lines denote linear regressions for each hydrologic group. There was a significant difference across hydrologic groups (ANCOVA, $\mathrm{p}<0.001)$ and year $(\mathrm{p}<0.05)$.
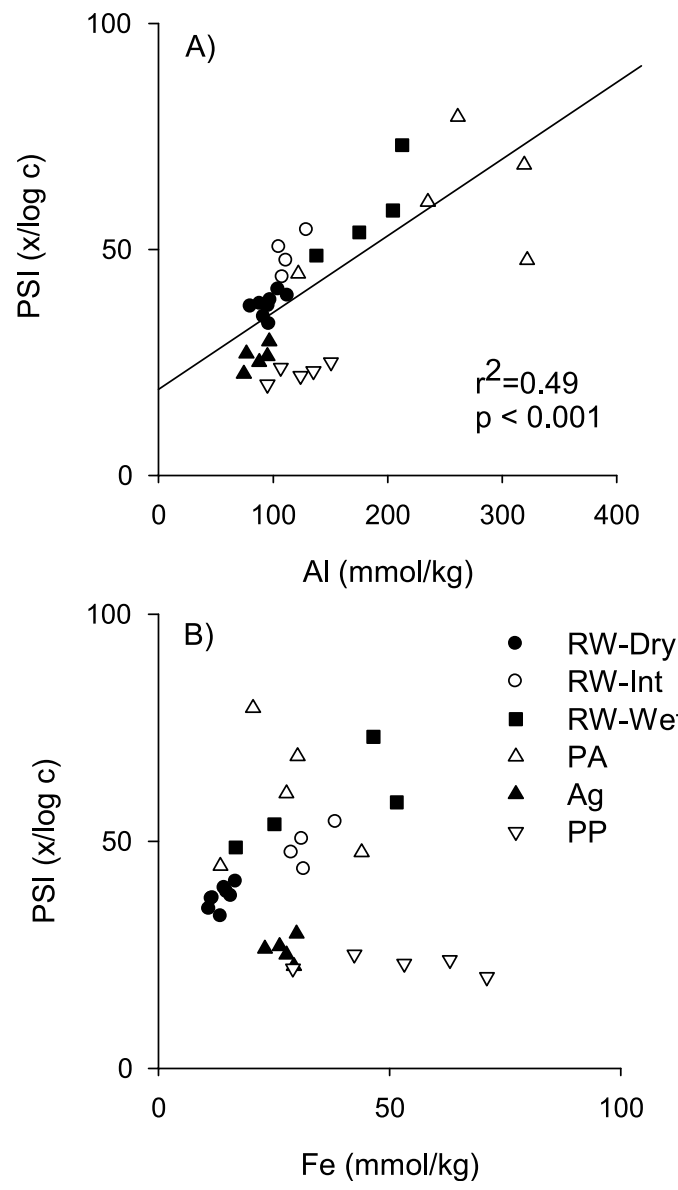

Figure 7. Relationships between single point phosphorus sorption index (PSI) and (a) $\mathrm{Al}_{\mathrm{ox}}$ and (b) $\mathrm{Fe}_{\mathrm{ox}}$. $\mathrm{Al}_{\mathrm{ox}}$ regressions, all data combined $\mathrm{r}^{2}=0.49, \mathrm{p}<0.0001$. PA, preservation area, PP, Palmetto Peartree Preserve; RW-Dry, restored wetland dry sites; RW-Int, intermittently flooded sites in restored wetland; RW-Wet, permanently flooded sites in the restored wetland. 
A)

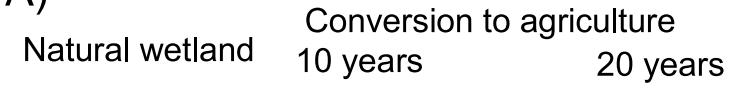

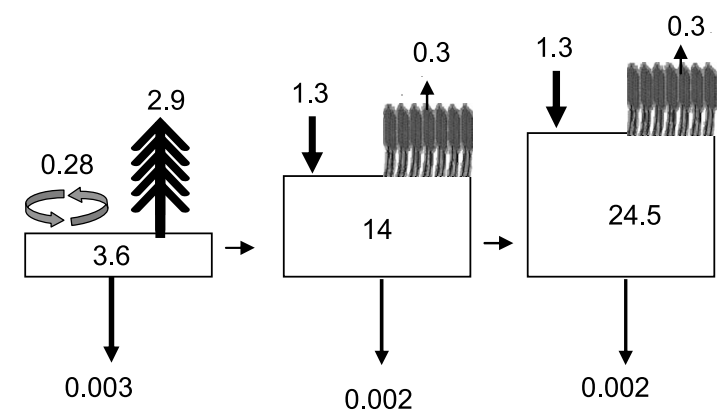

B) Wetland restoration

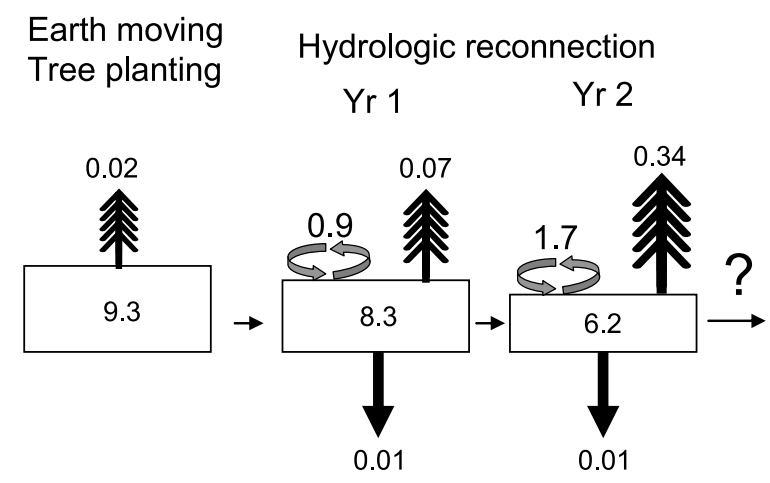

Figure 8. Estimated annual budgets of $\mathrm{P}$ over time to examine the sources and fates of legacy $\mathrm{P}$ at the Timberlake Restoration Project. Circular arrows indicate P (kmol/ha) actively cycling in sediment floc, algae and macrophytes. Number above trees in (a) natural wetland and (b) wetland restoration indicate $\mathrm{P}$ in tree biomass $(\mathrm{kmol} / \mathrm{ha})$. Fertilizer $\mathrm{P}$ application and $\mathrm{P}$ removal $\left(\mathrm{kmol} \mathrm{P} \mathrm{ha}^{-1} \mathrm{yr}^{-1}\right)$ through crop harvesting is shown in Figure 8a. Black downward facing arrows indicate losses through surface water $\left(\mathrm{kmol} \mathrm{ha}^{-1} \mathrm{yr}^{-1}\right)$, and numbers in boxes indicate soil TP pool $(\mathrm{kmol} / \mathrm{ha})$ integrated over the top $15 \mathrm{~cm}$. See text for more detail on how estimates and literature values were combined.

soils in these areas, average fertilizer application rates in the area are $1.3 \mathrm{kmol} \mathrm{P} \mathrm{ha}^{-1} \mathrm{yr}^{-1}$, with some of that $\mathrm{P}$ being removed by the harvesting of crops $\left(0.3 \mathrm{kmol} \mathrm{P} \mathrm{ha}^{-1} \mathrm{yr}^{-1}\right)$. We estimated that agricultural fertilizer application for 20 years (1985-2004) led to a total sixfold increase in the soil $\mathrm{P}$ pool (24.5 kmol $\mathrm{P} \mathrm{ha}{ }^{-1}$, Figure 8a), similar to TP we measured in the current agricultural field $\left(28.0 \mathrm{kmol} \mathrm{P} \mathrm{ha}^{-1}\right.$, $\mathrm{Ag}$ ). In 2006 when we first measured soil $\mathrm{P}$ at RW the P pool was $9.3 \mathrm{kmol} \mathrm{P} \mathrm{ha}^{-1}$ (Figure 8b). As part of the restoration, trees were planted in 2004, and based on tree growth measurements we estimate that they took up $0.30-5 \%$ of the TP pool over 3 years $\left(0.02,0.07\right.$ and $0.34 \mathrm{kmol} \mathrm{P}^{-1}$ in 2006, 2007 and 2008, respectively). We measured 0.01 and $0.005 \mathrm{kmol} \mathrm{P} \mathrm{ha}^{-1} \mathrm{yr}^{-1}$ losses through surface water in 2007 and 2008. Assuming statistical differences we observed reflect real changes in field TP stocks, soil TP declined by approximately $10-25 \%$ per year after hydrologic reconnection (Figure 6). Given that we cannot account for these declines in soil TP by either surface water losses $\left(0.01 \mathrm{kmol} \mathrm{P} \mathrm{ha}^{-1} \mathrm{yr}^{-1}\right)$ or tree uptake $\left(0.34 \mathrm{kmol} \mathrm{P} \mathrm{ha}^{-1}\right)$, we assume this $\mathrm{P}$ is entering an actively cycled pool within RW. This pool might include $\mathrm{P}$ taken up by herbaceous vegetation not included in our tree measurements, taken up by periphyton, in loose sediment floc, and $\mathrm{P}$ in soil solution and surface water. Given that RW had significantly higher TP $\left(6.2 \pm 1.3 \mathrm{kmol} \mathrm{P} \mathrm{ha}^{-1}\right)$ than the natural wetland $\left(3.7 \pm 2.0 \mathrm{kmol} \mathrm{P} \mathrm{ha}{ }^{-1}, \mathrm{~F}=17.9, \mathrm{df}=55, \mathrm{p}<0.001\right)$, we expect the difference of $2.6 \pm 2.4 \mathrm{kmol} \mathrm{P} \mathrm{ha}^{-1}$ could be lost from the site over time as it returns to its preagricultural state. Based on our assumptions of a constant surface water loss of $0.01 \mathrm{kmol} \mathrm{P} \mathrm{ha}^{-1} \mathrm{yr}^{-1}$, a constant tree $\mathrm{P}$ uptake of $0.34 \mathrm{kmol} \mathrm{P} \mathrm{ha}^{-1} \mathrm{yr}^{-1}$, and negligible changes in soil bulk density, our "back-of-the-envelope" estimate is that RW will continue to release P for 3-16 years.

\section{Discussion}

[24] We found consistent results that both natural and experimental hydrologic fluctuations can lead to increased $\mathrm{P}$ concentrations and export from a restored wetland ecosystem. Over the 2 years of this study, SRP concentrations of water leaving RW were 2.5 times higher than in a forested wetland (For) and an agricultural field (Ag) during the spring (Figure 2a). Higher concentrations, along with increased hydrologic flux, led to higher export of SRP and TP from the restored wetland (RW) than forested wetland (For) in spring and summer (Figures $2 \mathrm{~b}$ and $2 \mathrm{e}$ ). We found various lines of evidence that indicate that flooding can lead to release and export of various forms of P from RW. First the initial flooding as part of restoration increased SRP concentrations (Figure 3a), potentially due to the release of Fe-bound $\mathrm{P}$ due to anoxic conditions. Increases in water elevation due to precipitation events increased TP export more than SRP (Figure 2c), which suggests that storms mobilized particulate and organic forms of P. We found higher soil solution TP and lower soil TP in flooded than in dry soils (Figures 4 and 6), suggesting that flooded conditions facilitate soil $\mathrm{P}$ losses. We also found that a drawdown experiment during the summer increased SRP concentrations in both surface (Figure 3) and soil solution (Figure 5), suggesting that mineralization of organic $\mathrm{P}$ during oxic conditions can also be an important source of SRP.

[25] Our "back-of-the-envelope" calculation suggests that the Timberlake Restoration Project could continue to release legacy $\mathrm{P}$ for 3-16 years. We acknowledge that there is a lot of uncertainty around those estimates, and that our three key assumptions (constant plant uptake, constant hydrologic losses, and negligible changes in soil bulk density) are not likely to hold true over time. For example, it is unlikely that hydrologic export will be constant. During a year with high rainfall, we would expect that more SRP and TP would be exported in surface water. The export from TLRP will depend on hydrologic flux and the equilibrium concentrations of SRP and TP among soil, soil solution, and the overlying water [Reddy and DeLaune, 2008]. Similarly, it is unlikely that vegetation uptake will remain constant, it will likely increase exponentially and level off [Craft et al., 
2003]. Some of vegetation $P$ uptake will be incorporated into woody biomass, while some will be recycled through litter decomposition [Noe and Childers, 2007]. Vegetation will also play an important indirect role in determining $\mathrm{P}$ export by decreasing water yield through increased evapotranspiration as the trees mature and add more leaf surface area, and by increasing sedimentation and peat accumulation. We also acknowledge that the differences in soil TP over time in RW should be interpreted with caution given the relatively low level of soil sampling for such a large site.

[26] Considering these caveats, our estimates do provide a realistic benchmark to compare to previous studies that have documented temporary $\mathrm{P}$ release after reflooding former agricultural soils in the laboratory [Aldous et al., 2005, 2007; Pant and Reddy, 2003]. Previous reports of the duration of $\mathrm{P}$ release after flooding have ranged from months [Aldous et al., 2005, 2007] to 3 years [Pant and Reddy, 2003; Reddy and DeLaune, 2008]. Our estimates, based on field measurements, significantly extend that time frame and agree with other field studies in the literature. For example, a recent study found large $\mathrm{P}$ fluxes from a restored lake fringe wetland in Oregon 5-7 years after restoration [Duff et al., 2009]. The exact time period that TLRP will release legacy $\mathrm{P}$ is unknown, but our results illustrate the importance of hydrologic fluctuations and seasonal patterns in affecting both the timing and magnitude of $\mathrm{P}$ losses.

[27] Due to the large size of RW (440 ha) we expect there will be both spatial and temporal variations in $\mathrm{P}$ release and retention from patches within the site. Higher concentrations of soil solution SRP and TP in the RW-Wet soils (Figure 4) suggest these areas could be sources of P. However, the soils across the site have the capacity to sorb P (Figure 7), primarily controlled by $\mathrm{Al}_{\mathrm{ox}}$, as has been observed in other wetlands [Darke and Walbridge, 2000; Richardson, 1985]. We found higher concentrations of $\mathrm{Al}_{\mathrm{ox}}$ and higher sorption capacity (PSI) in the RW-Wet than the RW-Dry soils (Table 2), suggesting the RW-Wet soils could also function as $\mathrm{P}$ sinks. Seasonal differences due to both biological activity and extent of flooding could change soils across RW from sources to sinks of $\mathrm{P}$. The interplay between hydrologic fluctuations, leading to $\mathrm{P}$ release, and internal buffering by soils through sorption to noncrystalline forms of $\mathrm{Al}$, will determine the period of time before $\mathrm{P}$ cycling in RW returns to its preagricultural condition.

\subsection{Solute $P$ Losses}

[28] Increased $\mathrm{P}$ export from restored wetlands may have negative implications for downstream ecosystems. The Albemarle Sound is $5 \mathrm{~km}$ downstream and has historically low P concentrations (SRP usually less than $0.04 \mathrm{mg} / \mathrm{L}$ ) and N:P ratio of 20, both of which suggest $\mathrm{P}$ limitation of phytoplankton [Lin et al., 2007; Richardson, 1983]. The Albemarle-Pamlico sound has previously experienced problems with harmful algal blooms, hypoxia and massive fish kills in response to elevated nutrient delivery [Burkholder et al., 2004; Paerl et al., 2001]. SRP and TP concentrations leaving RW were 2.5 times higher than concentrations draining Ag and For in the spring. The low concentrations of SRP and TP leaving the agricultural field, even under fertilizer application, suggest that these soils tend to be $\mathrm{P}$ limited and have a high capacity to sorb and store $\mathrm{P}$, as we found (Table 2 and Figure 7). Our results suggest that the hydrologic reconnection of TLRP could lead to sustained releases of $P$ in the spring of each year as well as in response to drying and reflooding cycles due to droughts and storms. The spring timing of the $\mathrm{P}$ pulse could provide limiting $\mathrm{P}$ to phytoplankton during a critical time when their activity is increasing.

[29] Higher TP concentrations in soil solution at RW-Wet compared to RW-Dry and RW-Int (Table 1 and Figure 4), suggest that $P$ release is associated with reducing conditions in flooded areas. Our results agree with previous reports of $\mathrm{P}$ release after reflooding former agricultural fields from: soils formerly in dairy production in Florida [Pant and Reddy, 2003], peat soils in the Netherlands [Van Dijk et al., 2004], and soils from a restored lake fringe wetland in Oregon [Aldous et al., 2005, 2007; Duff et al., 2009]. Pant and Reddy [2003] reported rapid release of $P$ from solubilization of Fe-bound $\mathrm{P}$ after flooding soils that had been in dairy production, and the magnitude of flux decreased after subsequent flooding and drying cycles. In peat soils in the Netherlands, increases in soil and soil solution $\mathrm{pH}$ lead to increased $\mathrm{P}$ release due to stimulation of mineralization [Van Dijk et al., 2004]. Our results provide support for both of these mechanisms, as we observed high $\mathrm{P}$ concentrations under both reducing conditions and in response to an experimental drought during the summer.

\subsection{Hydrologic Fluctuations}

[30] To our knowledge, our study is the first to use an ecosystem-scale hydrologic manipulation to examine $\mathrm{P}$ dynamics. Most studies on the effects of hydrologic fluctuations on wetland soil $\mathrm{P}$ have been either in the laboratory [Aldous et al., 2005, 2007; Bostic and White, 2007; Corstanje and Reddy, 2004; Pant and Reddy, 2003], or at the lysimeter/well scale in the field [Van Dijk et al., 2004; Duff et al., 2009]. In the first drawdown experiment in February we did not see any changes in SRP concentrations during the drought or reflooding period. The lack of SRP increases after reflooding in February 2008 suggests that there was not a large pool of Fe-bound P that could have been released after reflooding. The relatively cold temperature (median $11.6^{\circ} \mathrm{C}$, range $2^{\circ}-21^{\circ} \mathrm{C}$ ) during this period meant there was low biological activity, thus mineralization was likely to be low during the drought period. During the summer drawdown experiment, we observed a fourfold increase in SRP concentrations during the low-water period (Figure $3 \mathrm{c}$ ). The water temperature in the summer experiment was much higher (median $25.6^{\circ} \mathrm{C}$, range $20.2^{\circ}-36.1^{\circ} \mathrm{C}$ ), suggesting that with the onset of oxic conditions, mineralization of organic $\mathrm{P}$ was stimulated. The increase in SRP concentration could have been due to decreasing the amount of water on the site. However, the increase in SRP concentration following the rainfall events after 28 August provide support for our hypothesis that mineralization in oxic sites in the upper layers of the soil led to the increased P. Increases in soil solution $\mathrm{P}$ during the dry period (Figure 5) also support our interpretation of increased mineralization during the dry period. Our drawdown experiments agreed with our weekly sampling in illustrating the importance of seasonal patterns in 
$\mathrm{P}$ transformations, something we would have missed in laboratory experiments under optimal conditions.

\subsection{Soil Changes}

[31] We were initially surprised by the difference in soil TP $\left(\mathrm{mol} / \mathrm{m}^{3}\right.$, Table 2$)$ between RW and the Ag site, which was also reflected in the difference between the soil TP after 20 years of agriculture (Figure $8 \mathrm{a}$ ) and the initial stage of wetland restoration (Figure $8 \mathrm{~b}$ ). We had expected these soils to be more similar given that TLRP was in agriculture for 20 years. We believe the large difference in soil TP between the Ag site and our initial sampling of RW (Table 2 and Figure 8) was due to earth moving that occurred prior to our sampling. We believe the filling of $53 \mathrm{~km}$ of vee ditches could have facilitated hydrologic and wind losses of TP and the redistribution of legacy fertilizer $\mathrm{P}$ to deeper horizons that were not covered by our soil sampling of the top $15 \mathrm{~cm}$. Previous studies have suggested removing topsoil that has received fertilizer before restoration to prevent $P$ release after reflooding [Bostic and White, 2007; Van Dijk et al., 2004]. It is possible that the earth moving at TLRP had a similar effect as removing the topsoil by decreasing soil TP available for mobilization. However, it is unclear if the earth movement led to the movement of $\mathrm{P}$ to deeper and more stable soil horizons [Reddy and DeLaune, 2008] or a $\mathrm{P}$ pulse to downstream ecosystems.

[32] We found consistent declines in soil TP in all three of the hydrologic groups within RW (Figure 6). Contrary to our expectations, all three hydrologic groups lost TP at a similar rate (Figure 6). Future research will continue to monitor TP losses from the three hydrologic groups to try to determine the fate of the legacy P. We were unable to account for the observed soil TP decline through surface water export and uptake by trees, suggesting that it might be entering an actively cycled pool. This actively cycled $\mathrm{P}$ can be in soil solution, loose sediments (floc), taken up by algae and nonwoody vegetation. Much of this rapidly cycled $\mathrm{P}$ pool is susceptible to hydrologic loss, potentially contributing to particulate $\mathrm{P}$ release during storms [Novak et al., 2007].

[33] Properties of the soils within RW were usually intermediate between the ecological end points we sampled (Table 2). RW-Dry soil tended to be more similar to the agricultural field, while RW-Wet was more similar to the reference wetlands. Various studies have reported differences in soil characteristics between natural and restored wetlands [Bruland and Richardson, 2005; Hogan et al., 2004; Meyer et al., 2008; Sundareshwar et al., 2009]. A recent study and literature review suggested it can take decades or centuries before restored wetlands recover the levels of soil properties, such as bulk density and soil organic matter, of natural wetlands [Ballantine and Schneider, 2009]. Bulk density in RW, particularly RW-Dry and RW-Int, reflected the $\sim 20$ years the site was under agriculture, as they had higher bulk density than found for either reference wetland sites (Table 2). Soil C concentrations per $\mathrm{kg}$ of soil were much higher in the reference wetlands, but when expressed per volume $\left(\mathrm{m}^{3}\right)$ the highest $C$ was in the RW-Wet soil (Table 2). The lowest-elevation portions of the former agricultural field are most similar to reference wetlands, likely because the areas were poorly drained during agriculture (and thus lost less soil organic matter to oxidation during agriculture).

\section{Conclusion}

[34] Our results demonstrate the potential for heightened and prolonged $\mathrm{P}$ export resulting from converting a former agricultural field to a hydrologically connected riverine wetland. Our best estimates of P cycling suggest that the Timberlake Restoration Project could continue to release legacy fertilizer $\mathrm{P}$ for up to 16 years. The time lag between restoration and return to preagriculture conditions should be considered in planning future mitigation needs and developing management strategies of restored wetlands; monitoring programs based on improved water quality conditions, for instance, should incorporate such lag effects into their protocol for sampling timing. The exact time frame for RW to return to its preagricultural state is unknown, but our results indicate that hydrologic fluctuations will play an important role in determining the loss of legacy $\mathrm{P}$. We found clear seasonal and storm effects on $\mathrm{P}$ export, suggesting that both the timing of restoration and active management of water levels might help alleviate these problems in future wetland restoration projects.

[35] Acknowledgments. Thanks to R. Bier, K. Ballance and M. BurkeScoll for help in the field and the laboratory. Thanks to C. Richardson and D. Richter for allowing us to do soil chemical analyses in their laboratories. The Bernhardt lab provided helpful suggestions on earlier versions of this manuscript. This research was supported by GDSMB private gift in support of basic research, grant 70233 from North Carolina's Water Resources Research Institute, and a grant to E. S. Bernhardt from the U.S. Department of Energy's Office of Science (BER) through the Coastal Center of the National Institute for Climatic Change Research at Tulane University. J. Morse was supported by an EPA Science to Achieve Results (STAR) Fellowship (FP916599), and M. Ardón was supported by NSF DBI-0805576.

\section{References}

Aldous, A., et al. (2005), Hydrologic regime controls soil phosphorus fluxes in restoration and undisturbed wetlands, Restor. Ecol., 13(2), 341-347.

Aldous, A. R., et al. (2007), Soil phosphorus release from a restoration wetland, Upper Klamath Lake, Oregon, Wetlands, 27(4), 1025-1035.

American Public Health Association (APHA) (1998), Standard Methods for the Examination of Water and Wastewater, 20th ed., Washington, D. C.

Ardón, M., et al. (2010), The water quality consequences of restoring wetland hydrology to a large agricultural watershed in the southeastern coastal plain, Ecosystems, 13(7), 1060-1078.

Axt, J. R., and M. R. Walbridge (1999), Phosphate removal capacity of palustrine forested wetlands and adjacent uplands in Virginia, Soil Sci. Soc. Am. J., 63(4), 1019-1031.

Ballantine, K., and R. Schneider (2009), Fifty-five years of soil development in restored freshwater depressional wetlands, Ecol. Appl., 19(6), $1467-1480$

Bedford, B. L., et al. (1999), Patterns in nutrient availability and plant diversity of temperate North American wetlands, Ecology, 80(7), 2151-2169

Bostic, E. M., and J. R. White (2007), Soil phosphorus and vegetation influence on wetland phosphorus release after simulated drought, Soil Sci. Soc. Am. J., 71(1), 238-244.

Bruland, G. L., and C. J. Richardson (2005), Spatial variability of soil properties in created, restored, and paired natural wetlands, Soil Sci. Soc. Am. J., 69(1), 273-284.

Burkholder, J., et al. (2004), Comparative impacts of two major hurricane seasons on the Neuse River and western Pamlico Sound ecosystems, Proc. Natl. Acad. Sci. U. S. A., 101(25), 9291-9296.

Carter, L. J. (1975), Agriculture-New frontier in coastal North Carolina, Science, 189(4199), 271-275.

Carter, M. R. (Ed.) (1993), Soil Sampling and Methods of Analysis, 823 pp., Lewis, Boca Raton, Fla. 
Corstanje, R., and K. R. Reddy (2004), Response of biogeochemical indicators to a drawdown and subsequent reflood, J. Environ. Qual., 33(6), 2357-2366.

Craft, C., P. Megonigal, S. Broome, J. Stevenson, R. Freese, J. Cornell, L. Zeng, and J. Sacco (2003), The pace of ecosystem development of constructed Spartina alterniflora marshes, Ecol. Appl., 13(5), 1417-1432.

Crozier, C. R. (2000), Fertilizer and lime management, in The North Carolina Corn Production Guide, N. C. Coop. Ext. Serv., N. C. State Univ., Raleigh.

Darke, A. K., and M. R. Walbridge (1994), Estimating noncrystalline and crystalline aluminum and iron by selective dissolution in a riparian forest soil, Commun. Soil Sci. Plant Anal., 25(11-12), 2089-2101.

Darke, A. K., and M. R. Walbridge (2000), Al and Fe biogeochemistry in a floodplain forest: Implications for P retention, Biogeochemistry, 51(1), $1-32$.

Duff, J. H., et al. (2009), Phosphorus and nitrogen legacy in a restoration wetland, Upper Klamath Lake, Oregon, Wetlands, 29(2), 735-746.

Hansson, L. A., et al. (2005), Conflicting demands on wetland ecosystem services: Nutrient retention, biodiversity or both?, Freshwater Biol., 50(4), 705-714.

Hogan, D. M., et al. (2004), Phosphorus retention and soil organic carbon in restored and natural freshwater wetlands, Wetlands, 24(3), 573-585.

Jenkins, J. C., et al. (2003), National-scale biomass estimators for United States tree species, For. Sci., 49(1), 12-35.

Lin, J., et al. (2007), Water quality gradients across Albemarle-Pamlico Estuarine System: Seasonal variations and model applications, J. Coastal Res., 23(1), 213-229.

Meyer, C. K., et al. (2008), Ecosystem recovery across a chronosequence of restored wetlands in the Platte River Valley, Ecosystems, 11, 193-208.

Mitsch, W. J., et al. (1979), Ecosystem dynamics: A phosphorus budget of an alluvial cypress swamp in southern Illinois, Ecology, 60, 1116-1124.

Needham, R. (2006), Implementation plan for agricultural restoration at Timberlake farms, Needham Environ. Inc., Wilmington, N. C.

Neely, H. (2008), Restoring farmland to wetlands: The potential for carbon credits in eastern North Carolina, 31 pp., Duke Univ., Durham, N. C.

Noe, G. B., and D. L. Childers (2007), Phosphorus budgets in Everglades wetland ecosystems: The effects of hydrology and nutrient enrichment, Wetlands Ecol. Manage., 15, 189-205.

Novak, J. M., et al. (2007), Dissolved phosphorus export from an animal waste impacted in-stream wetland: Response to tropical storm and hurricane disturbance, J. Environ. Oual., 36, 790-800.

Paerl, H. W., et al. (2001), Ecosystem impacts of three sequential hurricanes (Dennis, Floyd, and Irene) on the United States' largest lagoonal estuary, Pamlico Sound, NC, Proc. Natl. Acad. Sci. U. S. A., 98(10), 5655-5660.

Pant, H. K., and K. R. Reddy (2003), Potential internal loading of phosphorus in a wetland constructed in agricultural land, Water Res., 37, 965-972.

Poulter, B., and P. N. Halpin (2008), Raster modelling of coastal flooding from sea-level rise, Int. J. Geogr. Inf. Sci., 22(2), 167-182.

Poulter, B., et al. (2008), Applications of network analysis for adaptive management of artificial drainage systems in landscapes vulnerable to sea level rise, J. Hydrol., 357(3-4), 207-217.

Reddy, K. R., and R. D. DeLaune (2008), Biogeochemistry of Wetlands: Science and Applications, CRC Press, Boca Raton, Fla.

Reddy, K. R., et al. (1999), Phosphorus retention in streams and wetlands: A review, Crit. Rev. Environ. Sci. Technol., 29(1), 83-146.

Richardson, C. J. (1983), Pocosins: Vanishing wastelands or valuable wetlands?, BioScience, 33(10), 626-633.

Richardson, C. J. (1985), Mechanisms controlling phosphorus retention capacity in fresh-water wetlands, Science, 228(4706), 1424-1427.

Schlesinger, W. H. (1997), Biogeochemistry: An Analysis of Global Change, Academic, San Diego, Calif.

Schroeder, S., et al. (1997), Biomass estimation for temperate broadleaf forests of the US using inventory data, For. Sci., 43, 424-434.

Sundareshwar, P. V., et al. (2009), Nature versus nurture: Functional assessment of restoration effects on wetland services using Nuclear Magnetic Resonance Spectroscopy, Geophys. Res. Lett., 36, L03402, doi:10.1029/2008GL036385.

Van Dijk, J., et al. (2004), Restoring natural seepage conditions on former agricultural grasslands does not lead to reduction of organic matter decomposition and soil nutrient dynamics, Biogeochemistry, 71(3), 317-337.

Vepraskas, M. J., et al. (2004), Calibrating hydric soil field indicators to long-term wetland hydrology, Soil Sci. Soc. Am. J., 68(4), 1461-1469.

Verhoeven, J. T. A., et al. (2006), Regional and global concerns over wetlands and water quality, Trends Ecol. Evol., 21(2), 96-103.

Zedler, J. B. (2003), Wetlands at your service: Reducing impacts of agriculture at the watershed scale, Front. Ecol. Environ., 1(2), 65-72.

M. Ardón, E. S. Bernhardt, and J. L. Morse, Department of Biology, Duke University, Durham, NC 27708, USA. (marcelo.ardon@duke.edu)

M. W. Doyle, Department of Geography, University of North Carolina at Chapel Hill, Chapel Hill, NC 27599, USA

S. Montanari, Richard Gilder Graduate School, American Museum of Natural History, New York, NY 10024, USA. 